\title{
Oxidative Stress in Patients With Nongenital Warts
}

\author{
Sezai Sasmaz, ${ }^{1}$ Ozer Arican, ${ }^{1}$ and Ergul Belge Kurutas ${ }^{2}$ \\ ${ }^{1}$ Department of Dermatology, Faculty of Medicine, Kahramanmaras Sutcu Imam University, 46050 Kahramanmaras, Turkey \\ ${ }^{2}$ Department of Biochemistry, Faculty of Medicine, Kahramanmaras Sutcu Imam University, 46050 Kahramanmaras, Turkey
}

Received 21 December 2004; accepted 17 May 2005

\begin{abstract}
Comparison of oxidative stress status between subjects with or without warts is absent in the literature. In this study, we evaluated 31 consecutive patients with warts ( 15 female, 16 male) and 36 control cases with no evidence of disease to determine the effects of oxidative stress in patients with warts. The patients were classified according to the wart type, duration, number, and location of lesions. We measured the indicators of oxidative stress such as catalase (CAT), glucose-6-phosphate dehydrogenase (G6PD), superoxide dismutase (SOD), and malondialdehyde (MDA) in the venous blood by spectrophotometry. There was a statistically significant increase in levels of CAT, G6PD, SOD activities and MDA in the patients with warts compared to the control group $(P<$ $.05)$. However, we could not define a statistically significant correlation between these increased enzyme activities and MDA levels and the type, the duration, the number, and the location of lesions. We determined possible suppression of T cells during oxidative stress that might have a negative effect on the prognosis of the disease. Therefore, we propose an argument for the appropriateness to give priority to immunomodulatory treatment alternatives instead of destructive methods in patients with demonstrated oxidative stress.
\end{abstract}

\section{INTRODUCTION}

Warts is a common infectious disease caused by human papilloma virus (HPV), affecting the skin and mucosa $[1,2]$. Skin, the biggest organ of the body, constitutes a significant barrier against the infectious agents and produces many inflammatory mediators and other immune response factors [2]. Besides, a T-cell defect is suggested to lead to disease in cases infected with HPV [3]. In the treatment of the disease, drugs such as levamisole $[4,5]$, cimetidine [6,7], zinc [8], and topical imiquimod $[9,10]$, which have immunomodulatory effects, were also used and different success levels were reported.

Oxidative stress appears as a result of destroyed balance between oxidants and antioxidants in the body. Catalase (CAT), superoxide dismutase (SOD), and glucose-6phosphate dehydrogenase (G6PD) are the most important antioxidant enzymes in the cells [11]. SOD is a potent protective enzyme that can selectively scavenge the superoxide radicals by catalyzing their dismutation to hydrogen peroxide. The other antioxidative enzyme CAT converts hydrogen peroxide to water. G6PD catalyzes the conversion reaction of glucose to glucose-6-phosphate producing one of the main reducing equivalents of the cell NADPH. Malondialdehyde (MDA) is the end product of

Correspondence and reprint requests to Sezai Sasmaz, Department of Dermatology, Faculty of Medicine, Kahramanmaras Sutcu Imam University, 46050 Kahramanmaras, Turkey; drsasmaz@ksu.edu.tr lipid peroxidation and is accepted as the specific indicator of the oxidative stress [12]. Therefore, assessment of MDA is probably the most commonly applied method for the measurement of lipid peroxidation. Antioxidant enzymes in the cell reduce the oxidant activity and prevent the effects of oxidative stress [11]. It has been claimed that the balance of oxidants and antioxidants may play an important role in the spontaneous regression of HPV infections [13]. It is also thought that antioxidant systems have a connection with immunity [14].

In this study, the oxidative stress in a group of patients with nongenital warts was investigated.

\section{MATERIALS AND METHODS}

We evaluated 31 consecutive patients admitted to our dermatology clinic with untreated nongenital warts with verruca plantaris, verruca planus, and verruca vulgaris ( 15 female, 16 male) and 36 control cases with no evidence of disease. Patients with history of genital and filiformis warts, systemic or other cutaneous diseases, smoking, and vitamins or antiinflammatory medications were excluded. The patients were stratified according to duration of disease ( $\leq 1$ year versus $>1$ year), and the number of lesions ( $\leq 10$ and $>10$ lesions). The locations of the lesions were recorded as face, upper extremity, and lower extremity. A signed informed consent was taken from each subject.

Blood from forearm vein was collected into $5 \mathrm{~mL} \mathrm{Va-}$ cutainer tubes containing potassium EDTA. The blood samples were centrifuged at $1000 \mathrm{xg}$ for 10 minutes at $4^{\circ} \mathrm{C}$ 
TABLE 1. The mean values of catalase (CAT), glucose-6-phosphate dehydrogenase (G6PD), and superoxide dismutase (SOD) activities and malondialdehyde (MDA) levels in patients and control groups (mean \pm standard deviation).

\begin{tabular}{l|cccc}
\hline Subjects/statisical value & CAT $(\mathrm{U} / \mathrm{g} \mathrm{Hb})$ & G6PD $(\mathrm{U} / \mathrm{g} \mathrm{Hb})$ & SOD $(\mathrm{U} / \mathrm{g} \mathrm{Hb})$ & $\mathrm{MDA}(\mathrm{nmol} / \mathrm{mL})$ \\
\hline Patients $(n=31)$ & $17.7 \pm 5.2$ & $12.4 \pm 3.2$ & $3127 \pm 1176$ & $3.9 \pm 0.5$ \\
Control group $(n=36)$ & $15.4 \pm 2.0$ & $9.6 \pm 1.8$ & $2178 \pm 484$ & $2.1 \pm 0.2$ \\
$P(t$ test $)$ & .02 & $<.001$ & $<.001$ & $<.001$ \\
\hline
\end{tabular}

to remove plasma. The buffy coat on the erythrocyte sediment was separated carefully after the plasma was removed. The erythrocytes were washed three times with $0.9 \% \mathrm{NaCl}$ solution to remove the plasma remnant. After each procedure, erythrocyte saline mixture was centrifuged at $1000 \mathrm{xg}$ for 10 minutes at $4^{\circ} \mathrm{C}$. The hemolysates were prepared from the washed cells to measure the parameters of biochemical workup.

CAT activities were determined by measuring the decrease in hydrogen peroxide concentration at $230 \mathrm{~nm}$ by the method of Beutler [15]. Assay medium consisted of $1 \mathrm{M}$ Tris- $\mathrm{HCl}, 5 \mathrm{mM} \mathrm{Na}{ }_{2}$ EDTA buffer solution ( $\mathrm{pH} 8.0$ ), $1 \mathrm{M}$ phosphate buffer solution ( $\mathrm{pH} 7.0$ ), and $10 \mathrm{mM} \mathrm{H}_{2} \mathrm{O}_{2}$. CAT activity was expressed as $\mathrm{U} / \mathrm{g}$ hemoglobin.

SOD activity was measured according to the method described by Fridovich [16]. This method employs xanthine and xanthine oxidase to generate superoxide radicals, which react with $\mathrm{p}$-iodonitrotetrazolium violet (INT) to form a red formazan dye, which was measured at $505 \mathrm{~nm}$. Assay medium consisted of the $0.01 \mathrm{M}$ phosphate buffer, CAPS (3-cyclohexylamino-1propanesulfonic acid) buffer solution (50 mM CAPS, $0.94 \mathrm{mM}$ EDTA, saturated $\mathrm{NaOH}$ ) with $\mathrm{pH}$ of 10.2 , solution of substrate $(0.05 \mathrm{mM}$ xanthine, $0.025 \mathrm{mM}$ INT), and $80 \mathrm{U} / \mathrm{L}$ xanthine oxidase. SOD activity was expressed as $\mathrm{U} / \mathrm{g}$ hemoglobin.

G6PD activity was determined at $37^{\circ} \mathrm{C}$ according to Beutler [15]. The reaction mixture contained $1 \mathrm{M}$ Tris$\mathrm{HCl}$ of $\mathrm{pH}$ 8.0, $6 \mathrm{mM}$ G6P, Na salt, $2 \mathrm{mM}$ NADP, $0.1 \mathrm{M}$ $\mathrm{MgCl}_{2}$, and hemolysate in total volume of $3 \mathrm{~mL}$. One unit of enzyme activity is the amount that catalyzed the reduction of $1 \mathrm{mM}$ of NADP per minute.

Lipid peroxidation level in the plasma samples was expressed in MDA. It was measured according to procedure of Ohkawa et al [17]. The reaction mixture contained $0.1 \mathrm{~mL}$ sample, $0.2 \mathrm{~mL}$ of $8.1 \%$ sodium dodecyl sulfate (SDS), $1.5 \mathrm{~mL}$ of $20 \%$ acetic acid, and $1.5 \mathrm{~mL}$ of $0.8 \%$ aqueous solution of thiobarbituric acid (TBA). The mixture $\mathrm{pH}$ was adjusted to 3.5 and volume was finally made up to $4.0 \mathrm{~mL}$ with distilled water and $5.0 \mathrm{~mL}$ of the mixture of $n$-butanol and pyridine $(15: 1, \mathrm{v} / \mathrm{v})$ was added. The mixture was shaken vigorously. After centrifugation at $4000 \mathrm{rpm}$ for 10 minutes, the absorbance of the organic layer was measured at $532 \mathrm{~nm}$.

The hemoglobin level was measured with a spectronic-UV120 spectrophotometer by the method of cyanomethemoglobin.
Statistical assessments were carried out with SPSS 10.0 package program. Chi-square was used for the comparison of frequency, $t$ test for the comparison of averages, and Spearman correlation test for the assessment of correlation. For age-related analysis, both groups were divided into pediatric (aged up to 15 years) and adult (ages of 1655 years) subgroups and evaluated with Mann-Whitney $U$ test. Statistical difference was taken as $P<.05$.

\section{RESULTS}

Age and sex distributions of patient and control groups were determined as similar. The patients were between 5 and 55 (mean: $21 \pm 13$ ) years old and the members of the control group were between 5 and 50 (mean: $20 \pm 13$ ) years old. Lesions were located on the face of 7 patients, upper extremity of 11 patients, and lower extremity of 13 patients. The type of disease was verruca planus in 10 patients, verruca vulgaris in 8 patients, and verruca plantaris in 13 patients. The number of lesions was 10 and less in 19 patients, while it was more than 10 in 12 patients. The duration of the disease was shorter than 12 months in 26 patients, whereas it was longer in 5 patients.

Average values of the levels of antioxidant enzymes and MDA belonging to patient and control groups are summarized in Table 1. According to this, CAT, G6PD, $\mathrm{SOD}$, and MDA levels in the patient group were found to be statistically high. However, we could not define a statistically significant correlation between these increased enzyme activities and MDA levels and the type, the duration, the number, and the location of lesions.

In both patient and control groups, CAT, G6PD, SOD, and MDA parameters of pediatric age subgroup were not found different versus adult age subgroup $(P<.05)$. Activities of CAT in pediatric patients and G6PD in adult patients were found indifferent compared to the same-age control group subjects. However, the other oxidative stress parameters were found to be higher than the same-age control subjects (Tables 2 and 3 ).

\section{DISCUSSION}

In this prospective clinical study, we have chosen erythrocyte as a representative cell of the body to estimate the antioxidant enzyme activities in patients with nongenital warts because these enzymes are constitutively expressed in several cell lines including immature erythrocytes. On the other hand, erythrocytes are easy to obtain. 
TABLE 2. The mean values of catalase (CAT), glucose-6-phosphate dehydrogenase (G6PD), and superoxide dismutase (SOD) activities and malondialdehyde (MDA) levels in pediatric subgroups in both groups (mean \pm standard deviation).

\begin{tabular}{l|cccc}
\hline Subjects/statisical value & CAT $(\mathrm{U} / \mathrm{g} \mathrm{Hb})$ & G6PD $(\mathrm{U} / \mathrm{g} \mathrm{Hb})$ & SOD $(\mathrm{U} / \mathrm{g} \mathrm{Hb})$ & $\mathrm{MDA}(\mathrm{nmol} / \mathrm{mL})$ \\
\hline Patients $(n=12)$ & $15.2 \pm 4.4$ & $13.3 \pm 2.6$ & $3219 \pm 1098$ & $3.9 \pm 0.4$ \\
Control group $(n=18)$ & $15.5 \pm 2.1$ & $9.2 \pm 1.9$ & $2112 \pm 427$ & $2.1 \pm 0.1$ \\
$P($ Mann-Whitney $U)$ & .68 & .001 & .003 & $<.001$ \\
\hline
\end{tabular}

TABLE 3. The mean values of catalase (CAT), glucose-6-phosphate dehydrogenase (G6PD), and superoxide dismutase (SOD) activities and malondialdehyde (MDA) levels in adult subgroups in both groups (mean \pm standard deviation).

\begin{tabular}{l|cccc}
\hline Subjects/statisical value & CAT $(\mathrm{U} / \mathrm{g} \mathrm{Hb})$ & G6PD $(\mathrm{U} / \mathrm{g} \mathrm{Hb})$ & SOD $(\mathrm{U} / \mathrm{g} \mathrm{Hb})$ & $\mathrm{MDA}(\mathrm{nmol} / \mathrm{mL})$ \\
\hline Patients $(n=19)$ & $19.3 \pm 5.1$ & $11.8 \pm 3.2$ & $3068 \pm 1247$ & $3.8 \pm 0.5$ \\
Control group $(n=18)$ & $15.3 \pm 1.8$ & $10.1 \pm 1.7$ & $2242 \pm 539$ & $2.1 \pm 0.3$ \\
$P($ Mann-Whitney $U)$ & .01 & .13 & .04 & $<.001$ \\
\hline
\end{tabular}

The increased antioxidant enzyme activities of erythrocyte in the patients compared to healthy controls might be a peripheral response of the organism to increased oxidative stress. It can be put forward that increased antioxidant enzyme activities may reflect a preceding cellular oxidative stress or serve as a compensatory mechanism. Overproduction of both superoxide radicals and $\mathrm{H}_{2} \mathrm{O}_{2}$ may induce the expression of SOD and CAT enzymes. Since $\mathrm{H}_{2} \mathrm{O}_{2}$ is a neutral and highly liposoluble compound that can easily pass through the cytoplasmic and subcellular membranes, an excess amount of $\mathrm{H}_{2} \mathrm{O}_{2}$ found in or out of the cell membrane can pass through the erythrocyte membrane into the cytosol and thus cause an increase in the activities of CAT. In age-related analysis of our study, while the other antioxidant parameters were found to be increased in children with warts and CAT was not increased, this situation might be accounted for by the high value of intracellular superoxide anion radical in children.

The elevated MDA levels in patient group suggested the increased lipid peroxidation and thus oxidative stress still existed despite increased activities of the antioxidant enzymes. The lack of significant rise in the activity of G6PD in adult patients with warts despite the rise of other antioxidant parameters in the age-related analysis of this study might originate from the improved detoxification capacity in that age group.

HPV s are unenveloped double-stranded DNA viruses [18] and they infect human with the direct contact of infected materials to the epidermis [1]. They cause persistent infections [15] leading to malignant or benign neoplastic lesions on infected cutaneous and mucosal epithelium [19]. HPV resembles nonlytic viruses and does not cause death of the cell but leads to desquamation in the affected cells [20]. In a controlled molecular study, it was shown that the spontaneous regression of the disease may be related with cellular immunity, mainly $\mathrm{CD} 4^{+} \mathrm{T}$ lymphocytes and macrophages [21]. After AIDS and renal transplantation, observing many warts infections resistant to treatment in the immunosuppressed patients may lead us to think that a T-cell defect, which may create tendency to the disease, may constitute the basis for the disease [3]. Immunomodulatory effect of some drugs taking place among the treatment alternatives is also known $[4,5,6,7,8,9,10]$. For example, imiquimod, one of them, increases the interleukin- $1,-6$, and -8 and tumor necrosis factor- $\alpha$ and shows antiviral effects [9].

Reactive oxygen species (ROS) are toxic molecules and have important roles in many inflammatory skin diseases [14]. According to a view under dispute, T lymphocytes also produce ROS when faced with a stimulus. In some studies, it was put forward that antioxidant system stimulated T cells; on the other hand, in some other studies an opposite result was obtained and it was disclosed that oxidative stress suppressed T-cell activation [22].

It is known that all the viral proteins of HPV are potentially immunogenic. Besides, it reminds us of the thought that long-lasting warts' local immunosuppression or viral proteins could not be recognized. In addition to the low expression of early HPV proteins on basal epithelium, it may be thought that weak local release of cytokine may prevent the exact eradication of the disease [2]. The results we found lead us to think that when antioxidant system, which has close connection with immune system, overworks with exogenous stimulus, it suppresses $\mathrm{T}$ cells or slows them down. If increased antioxidant activity also activates cellular immunity, we would expect to see a faster regression in the disease and lesser relapse. Therefore, we propose an argument for the appropriateness to give priority to immunomodulatory treatment alternatives instead of destructive methods in patients with demonstrated oxidative stress. Moreover, as the views concerning the relation between $\mathrm{T}$ lymphocytes and oxidative stress are under dispute, new studies, which will clarify it, should be supported. 


\section{REFERENCES}

[1] Anderson FE. Warts. Fact and fiction. Drugs. 1985; 30(4):368-375.

[2] Sanclemente G, Gill DK. Human papillomavirus molecular biology and pathogenesis. J Eur Acad Dermatol Venereol. 2002;16(3):231-240.

[3] Bolton RA. Nongenital warts: classification and treatment options. Am Fam Physician. 1991;43(6): 2049-2056.

[4] Moncada B, Rodriguez ML. Levamisole therapy for multiple warts. Br J Dermatol. 1979;101(3):327-330.

[5] Amer M, Tosson Z, Soliman A, Selim AG, Salem A, Al-Gendy AA. Verrucae treated by levamisole. Int $J$ Dermatol. 1991;30(10):738-740.

[6] Choi YS, Hann SK, Park YK. The effect of cimetidine on verruca plana juvenilis: clinical trials in six patients. J Dermatol. 1993;20(8):497-500.

[7] Gooptu C, Higgins CR, James MP. Treatment of viral warts with cimetidine: an open-label study. Clin Exp Dermatol. 2000;25(3):183-185.

[8] Al-Gurairi FT, Al-Waiz M, Sharquie KE. Oral zinc sulphate in the treatment of recalcitrant viral warts: randomized placebo-controlled clinical trial. $\mathrm{Br} \mathrm{J}$ Dermatol. 2002;146(3):423-431.

[9] Arican O, Guneri F, Bilgic K, Karaoglu A. Topical imiquimod 5\% cream in external anogenital warts: a randomized, double-blind, placebocontrolled study. J Dermatol. 2004;31(8):627-631.

[10] Grussendorf-Conen EI, Jacobs S. Efficacy of imiquimod $5 \%$ cream in the treatment of recalcitrant warts in children. Pediatr Dermatol. 2002;19(3):263266.

[11] Mates JM, Perez-Gomez C, Nunez de Castro I. Antioxidant enzymes and human diseases. Clin Biochem. 1999;32(8):595-603.

[12] Freeman BA, Crapo JD. Biology of disease: free radicals and tissue injury. Lab Invest. 1982;47(5):412426.

[13] Giuliano AR, Siegel EM, Roe DJ, et al. Dietary intake and risk of persistent human papillomavirus (HPV) infection: the Ludwig-McGill HPV natural history study. J Infect Dis. 2003;188(10):1508-1516.

[14] Briganti S, Picardo M. Antioxidant activity, lipid peroxidation and skin diseases. What's new. J Eur Acad Dermatol Venereol. 2003;17(6):663-669.

[15] Beutler E. Red Cell Metabolism. A manual of Biochemical Methods, New York, NY: Grune and Stratton; $1975,261-265$.

[16] Fridovich I. Superoxide dismutases. Adv Enzymol Relat Areas Mol Biol. 1974;41(0):35-97.

[17] Ohkawa H, Ohishi N, Yagi K. Assay for lipid peroxides in animal tissues by thiobarbituric acid reaction. Anal Biochem. 1979;95(2):351-358.

[18] Severson J, Evans TY, Lee P, Chan T, Arany I, Tyring SK. Human papillomavirus infections: epidemiology, pathogenesis, and therapy. J Cutan Med Surg. 2001;5(1):43-60.
[19] Bernard HU. Established and potential strategies against papillomavirus infections. J Antimicrob Chemother. 2004;53(2):137-139.

[20] Stanley MA. Replication of human papillomaviruses in cell culture. Antiviral Res. 1994;24(1):1-15.

[21] Coleman N, Birley HD, Renton AM, et al. Immunological events in regressing genital warts. Am J Clin Pathol. 1994;102(6):768-774.

[22] Williams MS, Kwon J. T cell receptor stimulation, reactive oxygen species, and cell signaling. Free Radic Biol Med. 2004;37(8):1144-1151. 


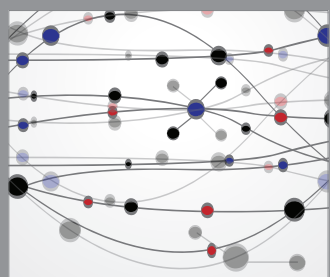

The Scientific World Journal
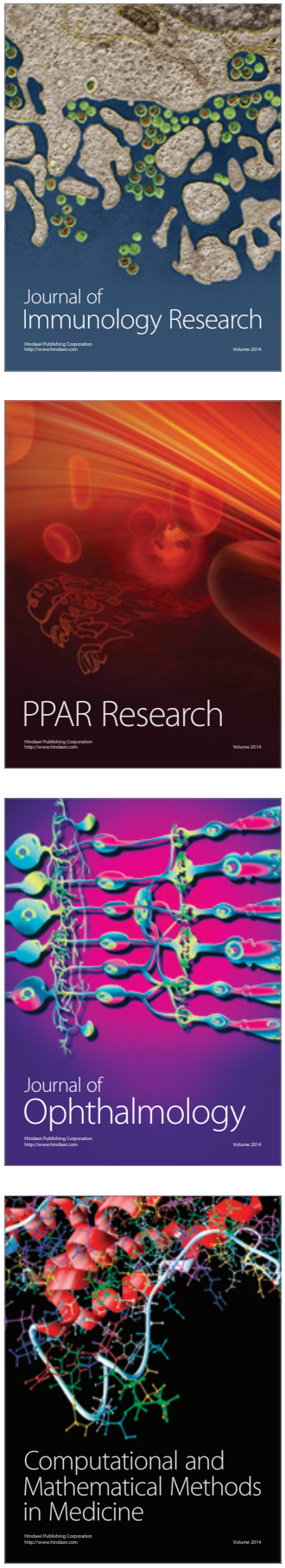

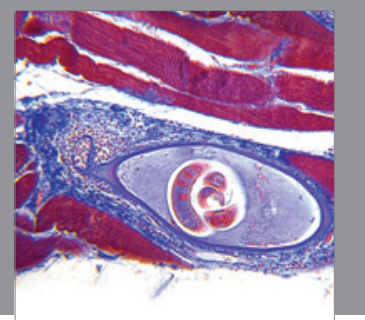

Gastroenterology

Research and Practice
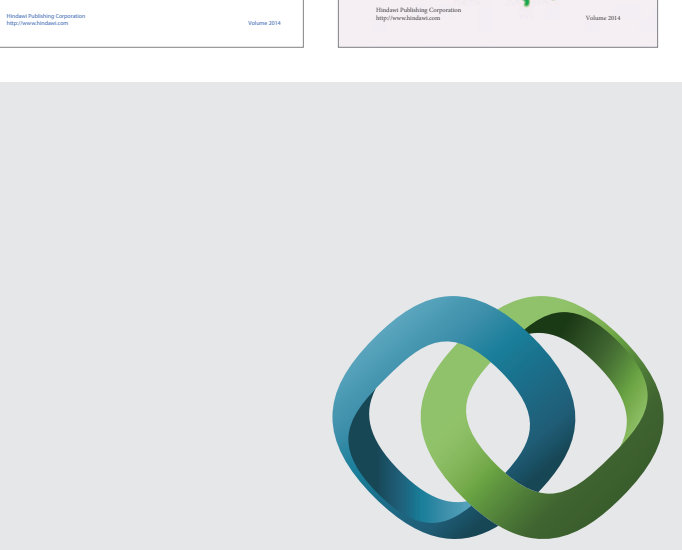

\section{Hindawi}

Submit your manuscripts at

http://www.hindawi.com
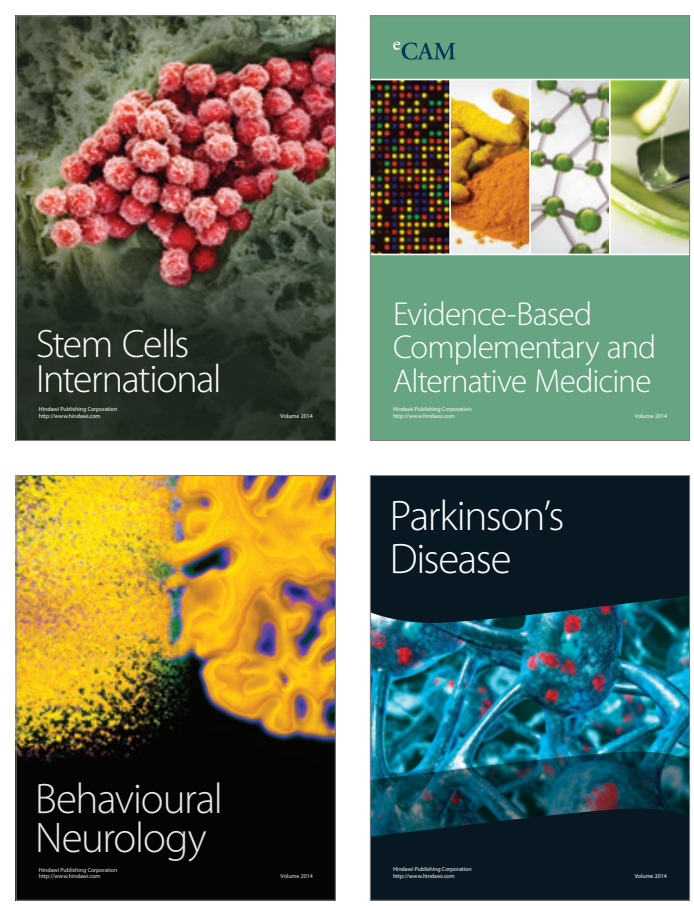

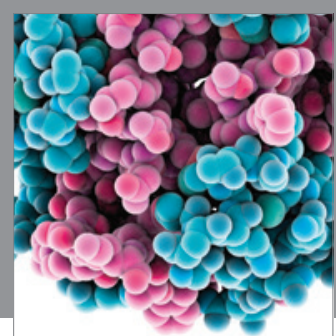

Journal of
Diabetes Research

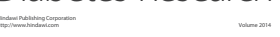

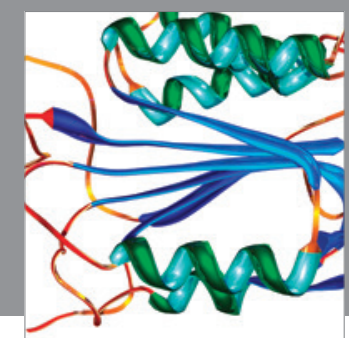

Disease Markers
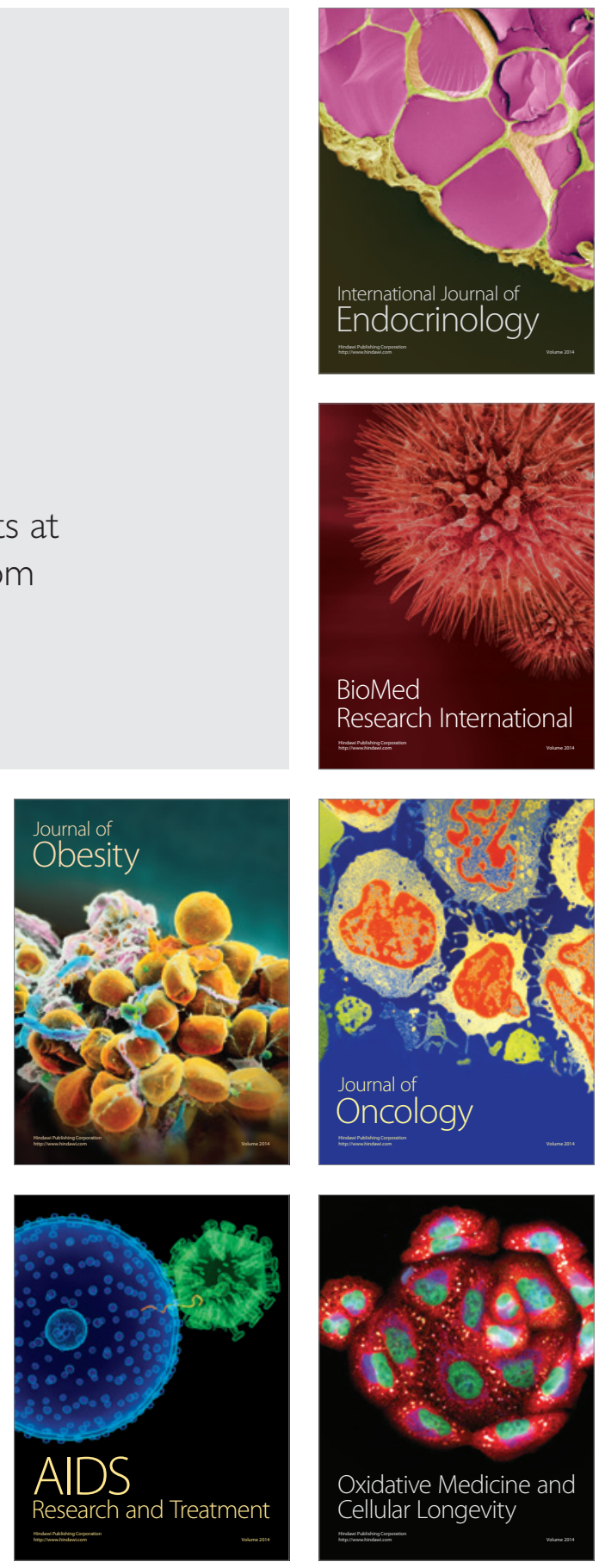